\title{
FRUIT FLIES (DIPTERA: TEPHRITIDAE) IN MANGO ORCHARDS IN THE MINAS GERAIS SEMI-ARID REGION ${ }^{1}$
}

\author{
DANIEL PEREIRA SOARES ${ }^{2 *}$, THAISA APARECIDA NERES DE SOUZA ${ }^{2}$, JULIANA DE OLIVEIRA SANTOS ${ }^{2}$, \\ TERESINHA AUGUSTA GIUSTOLIN ${ }^{2}$, CLARICE DINIZ ALVARENGA ${ }^{2}$
}

\begin{abstract}
We studied the diversity and level of infestation of fruit flies in mango orchards in a semi-arid region in the state of Minas Gerais, Brazil. Surveys were conducted in orchards in the irrigated perimeter of Jaíba municipality in northern Minas Gerais, from November 2016 to November 2017. Sampling was conducted by collecting mangoes and trapping flies in McPhail traps. Of the total adult flies obtained $(9,033)$, 8,902 specimens were Ceratitis capitata (Wiedemann) (Diptera: Tephritidae), making it the predominant species collected in the traps (91.3\%). 'Palmer' mango fruits were only infested with $C$. capitata, and showed high infestation rates (15.14 puparia $\mathrm{kg}^{-1}$ of fruit). The population peak of $C$. capitata coincided with the occurrence of mature mango fruits in the orchards. C. capitata was the most frequent and constant species identified in the survey and can be considered a dominant species.
\end{abstract}

Keywords: Mangifera indica. Ceratitis capitata. Anastrepha. Population monitoring. Faunistic analysis.

\section{MOSCAS-DAS-FRUTAS (DIPTERA: TEPHRITIDAE) EM POMARES DE MANGA NA REGIÃO SEMIÁRIDA DE MINAS GERAIS}

\begin{abstract}
RESUMO - Estudou-se a diversidade e infestação de moscas-das-frutas em manga na região semiárida do estado de Minas Gerais. Os levantamentos foram realizados em pomares localizados no perímetro de irrigação no município de Jaíba, no norte de Minas Gerais, no período de novembro de 2016 a novembro de 2017. A amostragem foi realizada por coleta de frutos e com armadilhas McPhail. Do total de adultos obtidos (9.033), 8.902 espécimes foram Ceratitis capitata (Wiedemann) (Diptera: Tephritidae), coletados predominantemente em armadilhas (91,3\%). Frutos de manga 'Palmer' foram infestados apenas por C. capitata, com altas taxas de infestação $\left(15,14\right.$ pupários. $\mathrm{kg}^{-1}$ de fruto). A população de C. capitata coincidiu com a ocorrência de frutos maduros de manga nos pomares. C. capitata é a espécie mais frequente e constante da pesquisa, sendo considerada uma espécie dominante.
\end{abstract}

Palavras-chave: Mangifera indica. Ceratitis capitata. Anastrepha. Levantamento populacional. Análise faunística.

\footnotetext{
${ }^{*}$ Corresponding author

${ }^{1}$ Received for publication in 06/18/2019; accepted in 04/27/2020.

Extracted from the first author's Master's dissertation.

${ }^{2}$ Department of Agricultural Sciences, Universidade Estadual de Montes Claros, Janaúba, MG, Brazil; daniel.pgpv@gmail.com - ORCID: 0000-0003-3089-6613, neres.thaisa@gmail.com - ORCID: 0000-0003-0681-4120, juh.julianaoliveira2015@gmail.com - ORCID: 00000003-4219-335X, teresinha.giustolin@unimontes.br - ORCID: 0000-0003-1948-2137, clarice.corsato@unimontes.br - ORCID: 0000-00027818-1062.
} 


\section{INTRODUCTION}

Brazil is the third largest producer of fresh fruits globally, after India and China (CARVALHO et al., 2017); however, it is only the twenty-third largest exporter. The northern region of Minas Gerais has been emerging as a fruit-producing hub (ALVARENGA et al., 2009), with mangoes being one of its main products. Most mango production is destined for the domestic market; in 2016, only $15.4 \%$ of production was exported (CARVALHO et al., 2017). Mangoes are one of the fruits with the greatest potential for increasing exports; however, despite favorable conditions, the main limitation is the presence of insect pests, including fruit flies (Diptera: Tephritidae) which are pests of quarantine importance (SANTOS et al., 2013). Several fruit fly species have assumed primary pest status in the national fruit-growing industry, by causing both direct damage to fruits and reducing production. In addition, the consequent breach of phytosanitary barriers prevents the export of fresh fruits (LEITE et al., 2017). Estimates of losses caused by fruit flies reach an annual value of about 120 million dollars (MOSCAMED, 2012).

Ceratitis capitata (Wiedemann) (Diptera: Tephritidae) is the most detrimental and worrying species of fruit fly because it is a cosmopolitan and invasive species. It is considered the most harmful tephritid in fruit farming (TRASSATO et al., 2017). In many surveys, this species was closely related to orchards in urban areas (SANTOS; ANDRADE; BITTENCOURT, 2008; AZEVEDO et al., 2010), including those in the northern region of Minas Gerais (ALVARENGA et al., 2010). With intensification in the exploration of fruit cultivation and extensive planting of primary hosts, a significant increase in the fruit fly population in fruit-growing areas is an imminent risk (HAJI et al., 2005; ALVARENGA et al., 2009). An example of this potential invasion occurred in the fruit-growing hub of the São Francisco Valley in Pernambuco, northeast Brazil, where a predominance of the genus Anastrepha Schiner (Diptera: Tephritidae) was previously observed in commercial orchards, whereas $C$. capitata was limited to urban areas (HAJI; MIRANDA, 2000). The expansion of fruit growing contributed to an increase in the population of $C$. capitata in growing areas (NASCIMENTO; CARVALHO; MALAVASI, 2000), and this species rose to absolute dominance in surveys carried out in the region (NASCIMENTO; CARVALHO, 2000; HAJI et al., 2005).

The northern region of Minas Gerais contains important irrigated agriculture projects focused on fruit production. The Jaíba Irrigation Project, the largest irrigated agriculture project in Latin America, ranges from smallholder farmers to large corporate irrigated areas and mainly produces bananas, lemons, and mangoes (OLIVEIRA; SILVA; PEREIRA,
2018). The bananas are destined for the national market while the lemon and mango production is destined for the domestic market and, to a lesser extent, for export. There is also papaya, watermelon, tangerine, table grape, orange, guava, passion fruit, and avocado production (IBGE, 2018).

To determine the species and populations of fruit flies in mango orchards, several population surveys have already been carried out in various producing regions of the country (FEITOSA et al., 2008; OLIVEIRA et al., 2009; LIMA et al., 2012; SANTOS et al., 2013). This research has shown that the population, diversity, and frequency of fruit fly species in mango orchards vary in relation to region, season, and cultivated mango variety. Knowledge of fruit fly species diversity and infestation rates, and constant monitoring of the fruit fly population are major requirements for the export of fresh fruit (SANTOS et al., 2013). Monitoring allows the characterization of the population in a qualitative and quantitative manner, and the identification of which species occur and their population dynamics allows the establishment of the best management strategy (NASCIMENTO; CARVALHO; MALAVASI, 2000; OLIVEIRA et al., 2009).

Owing to the economic impact of fruit flies as pests affecting mango production and export in Brazil, the species of fruit flies and their infestation rates were identified, and the population dynamics and faunistic composition of the fruit fly species were determined in commercial mango orchards in northern Minas Gerais.

\section{MATERIAL AND METHODS}

The survey was carried out in two commercial mango orchards located in the Irrigation District of Jaíba, in northern Minas Gerais, Brazil. The 'Palmer' mango orchard $\left(15^{\circ} 8^{\prime} 51.32^{\prime \prime} \mathrm{S} 43^{\circ} 58^{\prime}\right.$ $50.90^{\prime \prime} \mathrm{E}$ ), has a total area of 27.5 ha, and was subdivided into five 5.5-ha plots, each containing about 290 trees.ha $^{-1}$. This orchard is bordered to the north and south by a plantation of intercropped mahogany and banana, to the east by pasture, and to the west by areas of banana and lemon cultivation. Near the plot where the study was carried out, there was a domestic orchard with some 'Ubá' mango, guava, and acerola trees. The 'Ubá' mango orchard $\left(15^{\circ} 13^{\prime} 20.29^{\prime \prime} \mathrm{S} \quad 43^{\circ} 57^{\prime} 15.75^{\prime \prime} \mathrm{E}\right)$, had a total continuous area of 72 ha and about 180 plants ha ${ }^{-1}$. The orchard is bordered to the north and west by a sugarcane plantation, with a total area of approximately 900 ha. To the east it is bordered by grape plantations of the Niagara, Benitaka, and BRS Vitória varieties, with a total area of 30 ha. To the south is a 300-ha guava orchard, $200 \mathrm{~m}$ distant from the 'Ubá' mango orchard, separated by a 10-ha pumpkin plantation (between December 2016 and March 2017). During the study period, the guava 
orchard was unmanaged and did not receive any cultural treatment, and in May 2017, its felling began, ending at the end of July 2017.

In each of the orchards, a 5-ha plot was selected and a McPhail trap containing $500 \mathrm{ml}$ of an attractive solution, based on hydrolyzed maize protein diluted in water at $5 \%(\mathrm{v} / \mathrm{v})$, was installed. The traps were inspected weekly for 13 months (November/2016 to November/2017), when the bait in the traps was replaced and the specimens collected. The fruit flies were sexed, counted, and stored in $70 \%$ ethanol for later identification.

To evaluate the infestation of fruit flies in mango fruits, ripe or nearly ripe fruits were picked from the trees and/or collected from the ground, according to their availability in the orchards. Fruits were stored in plastic containers containing a thin layer of vermiculite, covered with thin organza fabric, and maintained under laboratory conditions $\left(25^{\circ} \mathrm{C} \pm 2{ }^{\circ} \mathrm{C} ; 60 \% \pm 10 \% \mathrm{RH} ; 12: 12 \mathrm{~h} \mathrm{~L}: \mathrm{D}\right)$. About 8 to 10 days after each collection, the vermiculite was sieved, and the fruits were dissected to collect puparia. The larvae and puparia were counted and stored in plastic containers containing moist vermiculite until the adult flies emerged. The flies were counted, sexed, and fixed in $70 \%$ ethanol to identify the species. Specimens of $C$. capitata were discarded after counting. Anastrepha spp. were identified based on the females. Infestation rates were calculated in puparia fruit ${ }^{-1}$ and puparia $\mathrm{kg}^{-1}$. Population fluctuations were based on the total number of specimens collected every month in the traps during the survey of the species.

The faunistic analyses were based on the insects captured in the traps. To characterize each community, the following indexes were calculated: Simpson's dominance index, Shannon index, richness, frequency, dominance, and constancy, using the methodology described by Silveira Neto (1976).

Simpson Index: An index of dominance, reflecting the probability of two individuals chosen at random in the community belonging to the same species. It ranges from 0 to 1 ; the higher the index, the greater is the probability of the individuals belonging to the same species. The greater the dominance, the lower the diversity. It is calculated as:

$$
\lambda=\sum_{1}^{\mathrm{S}} p_{i}^{2}
$$

where $p_{i}$ is the proportion of each species (frequency), for an $i$ ranging from 1 to $\mathrm{S}$ (Wealth).

Shannon Index: Assumes that a random sample is drawn from an infinitely large population, and that all species in the population are represented in the sample. The diversity tends to be higher with increasing index value. It is calculated as:

$$
H^{\prime}=-\sum_{l}^{S}\left(p_{i} \cdot \ln p_{i}\right)
$$

where $p_{i}$ is the frequency of each species, for an $i$ ranging from 1 to $\mathrm{S}$ (Richness).

Richness: The total number of species observed in the community.

Frequency: Proportion of individuals of a species in relation to the total number of individuals in the sample.

Constancy: Percentage of samples in which a given species was present:

$$
C=\frac{p \times 100}{N}
$$

where $p$ is the number of samples containing the species and $N$ is the total number of samples collected.

Constant species: present in more than $50 \%$ of the samples; samples;

Accessory species: present in $25-50 \%$ of the

Accidental species: present in less than $25 \%$ of the samples.

Dominance: A species is considered dominant when it presents a frequency higher than $1 / \mathrm{S}$, where $\mathrm{S}$ is the total number of species in the community (Richness).

The faunistic indexes were calculated considering only the females collected and identified, because Anastrepha spp. can only be identified in females.

A Spearman correlation analysis was performed between climatic factors that occurred up to 7 days before the trap was collected and the of fruit fly populations in the respective week of data collection, using the Action Stat software, version 3.7. The climatic data of precipitation, relative air humidity, air temperature, maximum temperature, minimum temperature, and accumulated solar radiation were obtained from the Meteorological Database for Teaching and Research, from the National Institute of Meteorology, for the automatic station in Mocambinho, Minas Gerais, Brazil.

\section{RESULTS AND DISCUSSION}

In total, 9,033 fruit flies were obtained from the McPhail traps and fruits, with 131 Anastrepha spp. specimens and 8,902 C. capitata specimens (Table 1). Of the total, $98.55 \%$ were captured in the traps and only $1.45 \%$ were obtained from the fruits, with the emergence of only $C$. capitata adults. Approximately $98 \%$ of all specimens caught in the traps were $C$. capitata, and six species of Anastrepha were captured (Table 2). 
Table 1. Fruit flies collected in two mango orchards, in the irrigated perimeter in northern Minas Gerais, Brazil.

\begin{tabular}{|c|c|c|c|c|c|c|c|}
\hline \multirow{2}{*}{ Species } & \multicolumn{3}{|c|}{ McPhail Traps } & \multicolumn{3}{|c|}{ Fruits } & \multirow{2}{*}{ Total } \\
\hline & Males & Females & Total & Males & Females & Total & \\
\hline Anastrepha spp. & 68 & 63 & 131 & 0 & 0 & 0 & 131 \\
\hline C. capitata & 2,727 & 5,400 & 8,127 & 393 & 382 & 775 & 8,902 \\
\hline Total & 2,795 & 5,463 & 8,258 & 393 & 382 & 775 & 9,033 \\
\hline
\end{tabular}

The Simpson and Shannon indices indicated little diversity and the dominance of one or more species. Anastrepha fraterculus (Wiedemann), A. obliqua (Macquart), and $C$. capitata were the dominant species; however, $C$. capitata can be considered the most important as it was observed most frequently and was the only constant species, i.e. it was present in more than $50 \%$ of the samples
(Table 2). A. fraterculus and A. obliqua, although also identified as dominant species, occurred at low frequencies, and were considered of accidental occurrence. The species $A$. sororcula Zucchi, $A$. pickeli Lima, A. turpiniae Stone, and A. zenildae Zucchi, were non-dominant and accidental, i.e., they only occurred sporadically in the orchards.

Table 2. Anastrepha spp. and C. capitata collected in McPhail traps in two commercial mango orchards in the irrigated perimeter in northern Minas Gerais, Brazil.

\begin{tabular}{lcccc}
\hline \multicolumn{1}{c}{ Species } & Number of females & Frequency (\%) & Constancy (\%) & Dominance \\
\hline A. fraterculus & 31 & 0.57 & $20.41(\mathrm{z})$ & $\mathrm{d}$ \\
A. obliqua & 14 & 0.26 & $22.45(\mathrm{z})$ & $\mathrm{d}$ \\
A. sororcula & 2 & 0.04 & $4.08(\mathrm{z})$ & $\mathrm{n}$ \\
A. pickeli & 3 & 0.05 & $6.12(\mathrm{z})$ & $\mathrm{n}$ \\
A. turpiniae & 2 & 0.04 & $4.08(\mathrm{z})$ & $\mathrm{n}$ \\
A. zenildae & 8 & 0.15 & $10.20(\mathrm{z})$ & $\mathrm{n}$ \\
C. capitata & 5,400 & 98.90 & $95.92(\mathrm{w})$ & $\mathrm{d}$ \\
\hline Total & 5,460 & & $1 / \mathrm{S}: 14.3 \%$ & \\
\hline
\end{tabular}

Richness (S): 7

Simpson: 0.9782

Shannon: 0.0751

Constancy: w: constant, y: accessory, z: accidental; Dominance: d: dominant, n: non-dominant.

C. capitata has become a serious problem for the mango industry in the irrigated perimeter of the Minas Gerais semi-arid region, as it is the most frequent, dominant, and constant fruit fly species in collections made in orchards. Thus, it is likely that this pest is already well-adapted to the 'Palmer' mango. It has also been reported in several other cultures in the region (ALVARENGA et al., 2007; QUERINO et al., 2014; CAMARGOS et al., 2015). Araújo et al. (2013) argue that $C$. capitata can become a key pest for guava cultures in semi-arid regions, as it was the most frequent species identified in their study and was classified as dominant. Dias and Silva (2014) also reported this species as the most frequent, dominant, highly abundant, and constant in orchards in southern Brazil. Owing to its high adaptive potential for new hosts and regions (PARANHOS et al., 2009), C. capitata is becoming a pest of great importance to the region.

In the northern region of Minas Gerais, $A$. sororcula, A. turpiniae, and $A$. zenildae are the most abundant species in guava fruits (ALVARENGA et al., 2009; QUERINO et al., 2014), which may explain their collection in the traps in this study, as the 'Ubá' mango orchard was close to a guava orchard. Anastrepha spp. are not considered a threat to mango orchards in the region, as they were not 
observed to infest fruits (Table 1). Mangoes are exotic fruit trees and, in this region, Anastrepha spp. use several native fruit trees as preferred hosts.

No adult Anastrepha were obtained from the mango fruits. The 'Palmer' variety mango fruits had the highest rates of infestation by fruit flies
(Table 3). Of the puparia obtained from the fruits, $98.75 \%$ were from the 'Palmer' variety, from which only $C$. capitata adults emerged, with a pupal viability of more than $65 \%$. In the 'Ubá' mangoes, although infestation was observed, there was no emergence of adults.

Table 3. Ceratitis capitata in 'Palmer' and 'Ubá' variety mango fruits collected in two commercial orchards in the irrigated perimeter in northern Minas Gerais, Brazil.

\begin{tabular}{lccccccc}
\hline \multirow{2}{*}{ Host } & \multirow{2}{*}{$\mathrm{N}^{\circ}$ fruits } & \multirow{2}{*}{ Fruit weight $(\mathrm{kg})$} & \multirow{2}{*}{$\mathrm{N}^{\circ}$ puparia } & \multirow{2}{*}{ Puparia fruit ${ }^{-1}$} & \multirow{2}{*}{ Puparia $\mathrm{kg}^{-1}$ of fruit } & \multirow{2}{*}{ Pupal viability (\%) } & \multicolumn{2}{c}{$\mathrm{N}^{\circ}$ Adults } & Males & Females & Total \\
\hline 'Palmer' mango & 202 & 78.459 & 1,188 & 5.88 & 15.14 & 65.23 & 393 \\
'Ubá' mango & 203 & 22.240 & 15 & 0.07 & 0.67 & 775 \\
\hline
\end{tabular}

The 'Palmer' mango fruits seem to have characteristics favorable to the larval development of C. capitata, as we observed high infestations in these fruits (Table 3 ), as well as high populations in the monitored orchard (Figure 1). C. capitata shows a preference for oviposition in exotic fruits (MORGANTE, 1991) and is greatly attracted to reddish hues (CYTRYNOWICZ; MORGANTE; SOUZA, 1982). It is also important to consider the nutritional quality of the host, as this may influence offspring survival and adult quality (COSTA et al., 2011). The choice of the oviposition substrate is fundamental for the survival and success of the offspring, as the larvae do not have mobility and depend on the nutritional resources selected by the females at the time of egg laying (JOACHIMBRAVO; SILVA-NETO, 2004; AZEVEDO et al., 2013).

The 'Palmer' mango proved to be an excellent host and multiplier of $C$. capitata, as it allowed complete development of the juvenile phase of the pest. The fruits of this variety are large with enough pulp and a thin peel, which facilitates oviposition by fruit flies, causing high infestation. In these fruits, the pupal viability was high (Table 3 ), allowing the population to increase rapidly with the availability of fruits susceptible to oviposition in the area (Figure 1A). According Sá et al. (2008) host species that allow pupal viability above $50 \%$ contribute to the maintenance and population increase of fruit flies. Thus, the 'Palmer' mango can be considered an important multiplier and maintainer of this pest in the fruit-producing hub of the Minas Gerais semi-arid region.

The low infestation in the 'Ubá' mango can be explained by the low commercial exploitation of this variety in the region, since it is more commonly found in domestic orchards. 'Ubá' mango fruits may present features that restrict larval development or prevent hatching and/or complete development, as signs of oviposition and the eggs of $C$. capitata were present in the collected fruits. According to Rossetto et al. (2009), the latex of fruits that are resistant to fruit flies probably contains characteristics inappropriate for contact with eggs and/or larvae. Oliveira et al. (2016) identified several chemical compounds in 'Ubá' mango fruits, including tannins and phenolic compounds, which show increasing concentration in the fruit as a function of maturation stage. These compounds have recognized deleterious action against insects; they act in the defense of the plants and reduce palatability, digestibility, and the growth and development of insects owing to the inactivation of digestive enzymes (CAVALCANTE; MOREIRA; VASCONCELOS, 2006; REZENDE et al., 2016; SIMÕES et al., 2017).

The populations of fruit flies in both monitored orchards varied during the survey period. Larger $C$. capitata populations occurred when there were ripe fruits in the orchards (Figure 1A). The Anastrepha spp. occurred in greater numbers during the off-season of the 'Palmer' mangoes and this also coincided with the fruiting season of the native fruits of the region (Figure 1B). In the 'Ubá' mango orchard, the presence of fruit flies occurred at two distinct periods of the year (Figure 2). From November 2016 to January 2017, the population of C. capitata was higher than that of Anastrepha spp. with the population peak occurring in December. From this time, the population of C. capitata declined drastically, whereas the population of Anastrepha spp. began to rise until it reached its peak in August 2017. There was no correlation between the populations of $C$. capitata and Anastrepha spp. and climatic factors. 


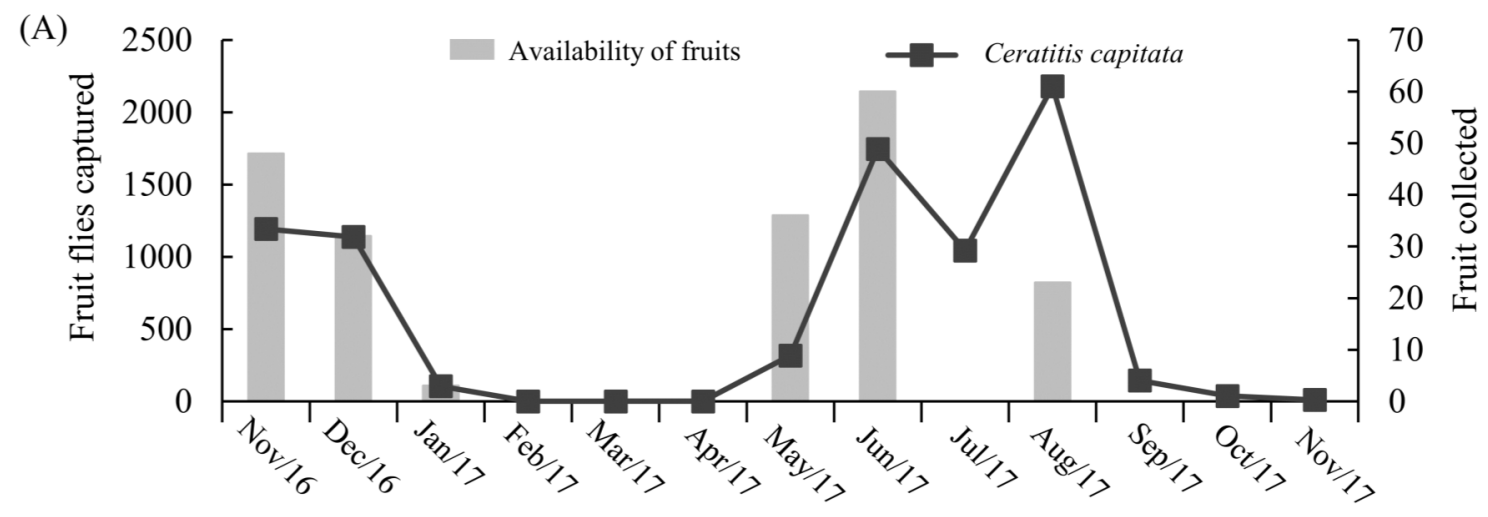

Evaluation period

(B)

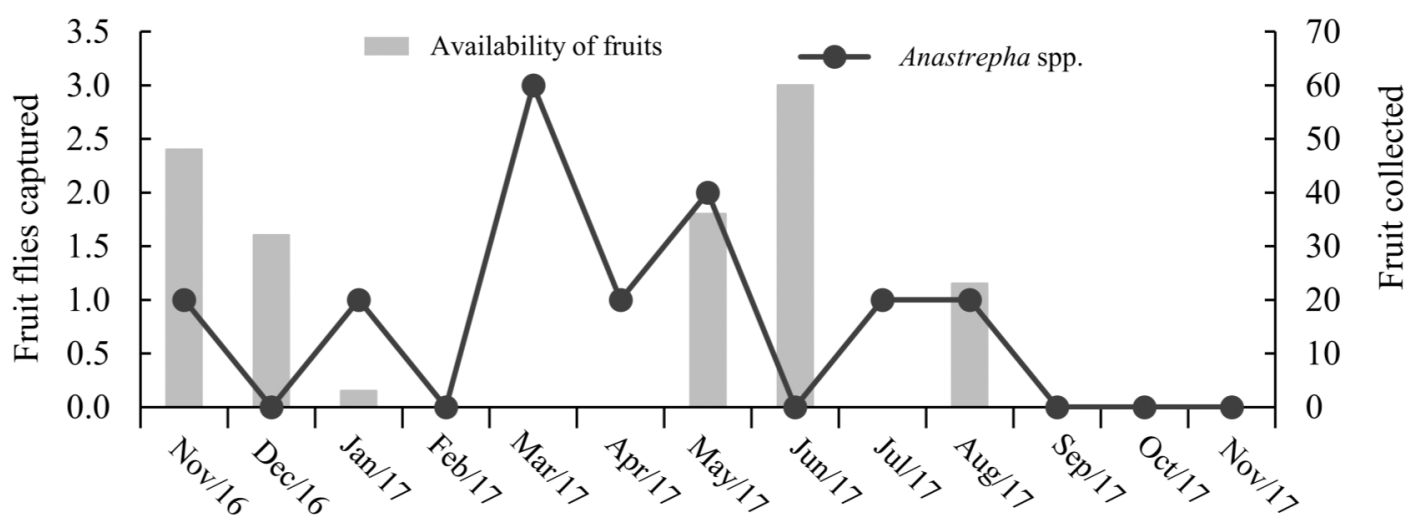

Evaluation period

(C)

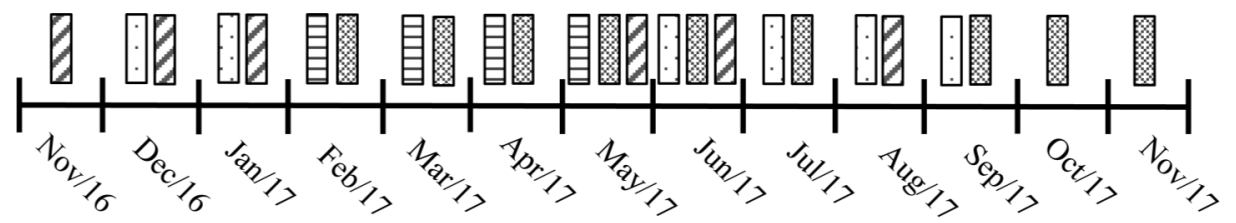

目Vegetating Fruits “chumbinho" - "egg”

Figure 1. Population fluctuation of fruit flies collected in McPhail traps in a commercial 'Palmer' mango orchard, in the irrigated perimeter in northern Minas Gerais, Brazil. (A) Population fluctuation of C. capitata; (B) Population fluctuation of Anastrepha spp.; (C) Stages of vegetative and reproductive development of 'Palmer' mango orchard.

In previous surveys in northern Minas Gerais, infested mango fruits were only found in orchards in urban areas (ALVARENGA et al., 2010). There were no records of this pest causing damage in commercial orchards in rural areas until their detection in papaya fruits (ALVARENGA et al., 2007) and guava orchards with low infestation rates (QUERINO et al., 2014), and in irrigated coffee plantations with high infestation rates (CAMARGOS et al., 2015). It is postulated that the irrigated coffee cultivation in the region attracted $C$. capitata to these areas, as coffee is considered a preferred host of this pest (RAGA et al., 2002; MONTES et al., 2012). Montes et al. (2012) suggest that coffee planting in plantations close to fruit plants susceptible to the fruit flies requires adequate management. Coffee serves as a multiplier of this pest during low occurrence of other fruits. Thus, emerging adults from coffee plantations migrate to other areas, infesting the fruit trees in the harvest season. In the region of Jaíba, the presence of several fruits throughout the year is common, especially in mango 
cultures, which are managed to obtain successive harvests in order to escape the harvest periods of other regions of the country and obtain windows in the market. In this manner, populations of $C$. capitata have found ideal conditions to stablish and multiply, reaching high population levels, especially in 'Palmer' mango orchards (Figure 1).

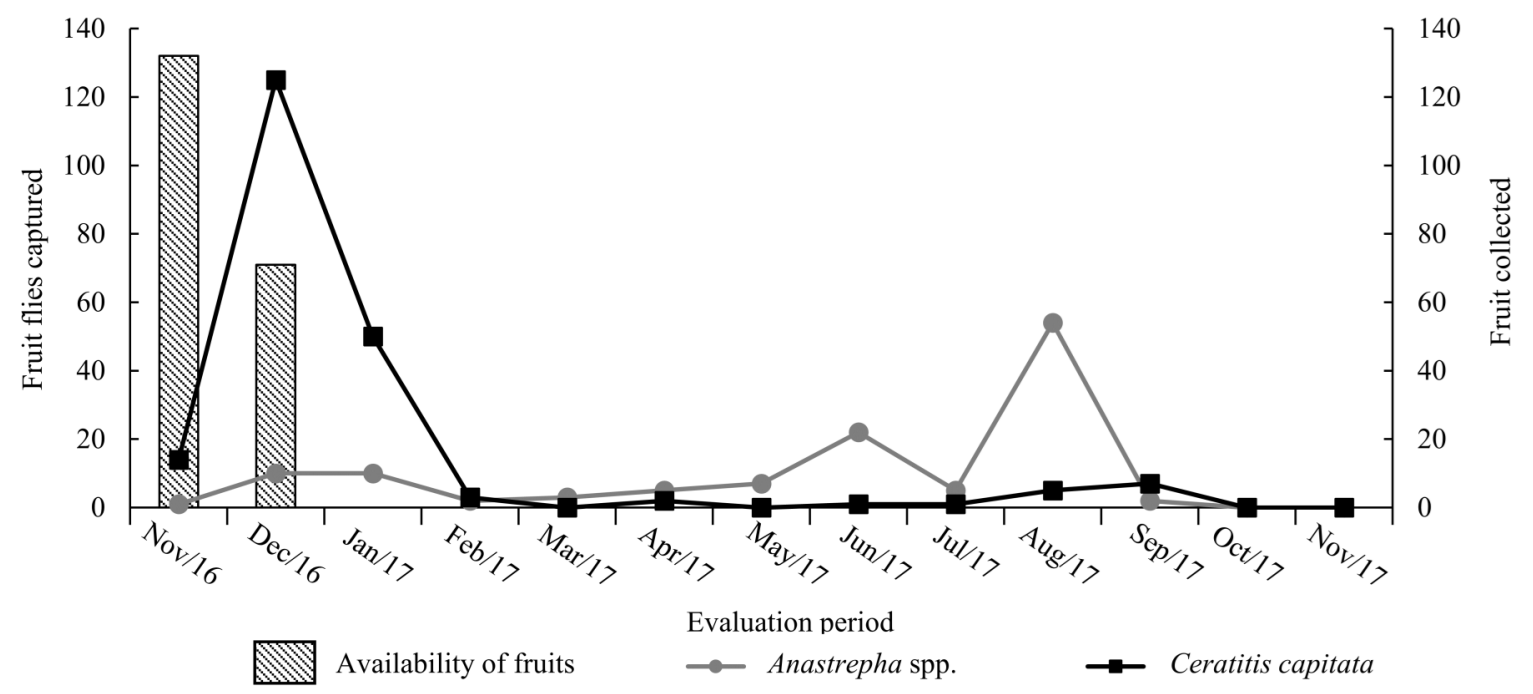

Figure 2. Population fluctuation of fruit flies (Anastrepha spp. and C. capitata) collected in McPhail traps in a commercial 'Ubá' mango orchard, in the irrigated perimeter in northern Minas Gerais, Brazil.

The large populations of $C$. capitata caught in the McPhail traps may be a reflection of the high infestation in mature mango fruits. Population peaks reached numbers greater than 1,000 captured flies per month. The abundant availability of 'Palmer' mango fruits has resulted in the population of $C$. capitata remaining constant. $C$. capitata has high reproductive capacity (RAGA et al., 1996) and its potential is associated with the availability of hosts; population increases of this pest occur in a rapid and intense manner, resulting in the high populations observed. In addition, it was observed in this study that climatic factors did not influence the tephritid populations, indicating that the presence of host fruits is the most influential factor on the population of fruit flies (MONTES et al., 2011; DUARTE; GALLI; PAZINI, 2012; DUARTE et al., 2014; CAMARGOS et al., 2015).

After the felling of the guava orchard near the 'Ubá' mango orchard, the fruit fly population reached zero, probably because of the lack of other nearby hosts. In addition to the guava orchard, the 'Ubá' mango orchard also had extensive sugarcane fields surrounding it, with no hosts for the fruit flies.

Among the fruit flies present in the mango orchards in the north of Minas Gerais, C. capitata was found to be the most frequent, constant, and dominant species. Anastrepha spp. occurred at a low frequency in the mango orchards in the Minas Gerais semi-arid region and can be considered of accidental occurrence. The 'Palmer' mangoes cultivated in northern Minas Gerais are considered a C. capitata host because the fruits showed high infestation rates. The large fly populations in the orchards can be directly linked to the presence of these fruits in the maturation phase.

\section{CONCLUSIONS}

Anastrepha spp. occurred at a low frequency in the mango orchards and can be considered of accidental occurrence. C. capitata was the most frequent and constant species is in the survey and can be considered a dominant species in the mango orchards in the Minas Gerais semi-arid region. The 'Palmer' mangoes cultivated in northern Minas Gerais are considered a C. capitata host.

\section{ACKNOWLEDGEMENTS}

This study was funded in part by the Coordination for the Improvement of Higher Education Personnel (CAPES) - Financial Code 001.

\section{REFERENCES}

ALVARENGA, C. D. et al. Moscas-das-frutas (Diptera: Tephritidae) em pomares da área urbana no norte de Minas Gerais. Revista Caatinga, 23: 25-31, 2010. 
ALVARENGA, C. D. et al. Moscas-das-frutas (Diptera: Tephritidae) e seus parasitoides em plantas hospedeiras de três municípios do norte de Minas Gerais. Arquivos do Instituto Biológico, 76: 195 204, 2009.

ALVARENGA, C. D. et al. Ocorrência de Ceratitis capitata Wied. (Diptera: Tephritidae) em frutos de mamoeiro em Minas Gerais. Neotropical Entomology, 36: 807-808, 2007.

ARAÚJO, E. L. et al. Moscas-das-frutas (Diptera: Tephritidae) em um pomar de goiabeira, no semiárido brasileiro. Revista Brasileira de Fruticultura, 35: 471-476, 2013.

AZEVEDO, F. R. et al. Análise faunística e flutuação populacional de moscas-das-frutas (Diptera: Tephritidae) em pomares comerciais de goiaba na região do cariri cearense. Arquivos do Instituto Biológico, 77: 33-41, 2010.

AZEVEDO, F. R. et al. Influência da cor e forma dos frutos artificiais e quadrantes na copa da goiabeira sobre a atração de Anastrepha spp. para oviposição. Revista Científica Eletrônica de Agronomia, 23: 34-45, 2013.

CAMARGOS, M. G. et al. Moscas-das-frutas (Diptera: Tephritidae) em cafezais irrigados no norte de Minas Gerais. Coffee Science, 10: 28-37, 2015.

CARVAlHO, C. et al. Anuário Brasileiro da Fruticultura. 1. ed. Santa Cruz do Sul, RS: Editora Gazeta Santa Cruz, 2017. 88 p.

CAVALCANTE, G. M.; MOREIRA, A. F. C.; VASCONCELOS, S. D. Potencialidade inseticida de extratos aquosos de essências florestais sobre moscabranca. Pesquisa Agropecuária Tropical, 41: 9-14, 2006.

COSTA, A. M. et al. Influence of different tropical fruits on biological and behavioral aspects of the Mediterranean fruit fly Ceratitis capitata (Wiedemann) (Diptera, Tephritidae). Revista Brasileira de Entomologia, 55: 355-360, 2011.

CYTRYNOWICZ, M. MORGANTE, J. S.; SOUZA, H. M. L. Visual responses of South American fruit flies, Anastrepha fraterculus, and Mediterranean fruit flies, Ceratitis capitata, to colored rectangles and spheres. Environmental Entomology. 11: 1202 $-1210,1982$.

DIAS, N.; SILVA, F. F. Moscas-das-frutas (Diptera: Tephritidae e Lonchaeidae) na região da fronteira Oeste do Rio Grande do Sul. Revista de Ciências Agrárias, 57: 29-34, 2014.
DUARTE, R. T. et al. Atrativos alimentares no monitoramento populacional de moscas das frutas (Diptera: Tephritidae) em pomar de goiaba. Nucleus, 11: 45-53, 2014

DUARTE, R. T.; GALLI, J. C.; PAZINI, W. C. Dinâmica populacional de moscas-das-frutas (Diptera: Tephritidae) em pomar de goiaba no município de Jaboticabal - SP. Agroecossistemas, 4: 33-41, 2012.

FEITOSA, S. S. et al. Flutuação populacional de moscas-das-frutas (Diptera: Tephritidae) associadas a variedades de manga no município de José de Freitas - Piauí. Revista Brasileira de Fruticultura, 30: 112-117, 2008

HAJI, F. N. P. et al. Monitoramento de moscas-dasfrutas no Submédio do Vale do São Francisco. In: MENEZES, E. A.; BARBOSA, F. R. (Eds.). Pragas da mangueira: monitoramento, nível de ação e controle. Petrolina, PE: Embrapa Semiárido, 2005. cap. 4, p. 85-86.

HAJI, F. N.; MIRANDA, I. D. G. Moscas-das-frutas nos Estados Brasileiros - Pernambuco. In: MALAVASI, A.; ZUCCHI, R. A. (Eds.). Moscasdas-frutas de importância econômica no Brasil: conhecimento básico e aplicado. Ribeirão Preto, SP: Holos, 2000. cap. 33, p. 229-233.

INSTITUTO BRASILEIRO DE GEOGRAFIA E ESTATÍSTICA - IBGE. Produção Agrícola Municipal, 2018. Disponível em: <https:// sidra.ibge.gov.br/tabela/5457>. Acesso em: 21 mar 2020.

JOACHIM-BRAVO, I. S.; SILVA-NETO, A. M. Aceitação e preferência de frutos para oviposição em duas populações de Ceratitis capitata (Diptera, Tephritidae). Iheringia, Série Zoologia, 92: 171176,2004

LEITE, S. A. et al. Fruit files and their parasitoids in the fruit growing region of Livramento de Nossa Senhora, Bahia, with records of unprecedented interactions. Revista Brasileira de Fruticultura, 39: 1-10, 2017

LIMA, A. B. et al. Ocorrência de moscas-das-frutas (Diptera: Tephritidae) em mangueiras (Mangifera indica L.) em Boa Vista, Roraima. Revista Agro@mbiente, 6: 179-183, 2012.

MONTES, S. M. N. M. et al. Moscas-das-frutas em cultivares de cafeeiros de Presidente Prudente, SP. Coffee Science, 7: 99-109, 2012.

MONTES, S. M. N. M. et al. Dinâmica populacional e incidência e moscas-das-frutas e parasitoides em 
cultivares de pessegueiros (Prunus persica L. Batsch) no município de Presidente Prudente - SP. Revista Brasileira de Fruticultura, 33: 402-411, 2011.

MORGANTE, J. S. Moscas-das-frutas (Tephritidae): características biológicas, detecção e controle. 1. ed. Brasília, DF: MAARA/SENIR, 1991. 19 p. (Boletim Técnico, 2).

MOSCAMED. 2012. Linhas de ação. Bahia: Biofábrica Moscamed Brasil. Disponível em: <http:// moscamed.org.br/linhas-de-acao/>. Acesso em: 24 mar. 2020.

NASCIMENTO, A. S.; CARVALHO, R. D. S. Manejo integrado de moscas-das-frutas. In: MALAVASI, A.; ZUCCHI, R. A. Moscas-dasfrutas de importância econômica no Brasil: conhecimento básico e aplicado. Ribeirão Preto, SP: Holos, 2000. cap. 22, p. 169-173.

NASCIMENTO, A. S.; CARVALHO, R. D. S.; MALAVASI, A. Monitoramento populacional. In: MALAVASI, A.; ZUCCHI, R. A. Moscas-dasfrutas de importância econômica no Brasil: conhecimento básico e aplicado. Ribeirão Preto, SP: Holos, 2000. cap. 13, p. 109-112.

OLIVEIRA, B. G. et al. Chemical profile of mango (Mangifera indica L.) using electrospray ionisation mass spectrometry (ESI-MS). Food Chemistry, 204: 37-45, 2016.

OLIVEIRA, I. M.; SILVA, A. S.; PEREIRA, L. A. G. SIG aplicado ao estudo da produção e comercialização de frutas nos municípios de Janaúba e Jaíba - MG. Geofronter, 1: 7-28, 2018.

OLIVEIRA, J. J. D. et al. Espécies e flutuação populacional de moscas-das-frutas em um pomar comercial de mangueira, no litoral do estado do Ceará. Revista Caatinga, 22: 222-228, 2009.

PARANHOS, B. J. et al. A importância da técnica do inseto estéril (TIE) para a fruticultura nordestina. In: CARVAlHO, J. M. M. de (Org.). Apoio do BNB à pesquisa e desenvolvimento da fruticultura regional. Fortaleza, CE: Banco do Nordeste do Brasil, 2009. cap. 2, p. 29-51.

QUERINO, R. B. et al. Fruit fly (Diptera: Tephritidae) Community in guava orchards and adjacent fragments of native vegetation in Brazil. Florida Entomologist, 97: 778-786, 2014.

RAGA, A. et al. Occurrence of fruit flies in coffee varieties in the State of São Paulo, Brasil. Boletín de Sanidad Vegetal de Plagas, 28: 519-524, 2002.
RAGA, A. et al. Sensibilidade de ovos de Ceratitis capitata (Wied., 1824) irradiados em dieta artificial e em frutos de manga (Mangifera indica L.). Scientia Agricola, 53: 114-118, 1996.

REZENDE, F. M. et al. Vias de síntese de metabólitos secundários em plantas. In: Hidalgo, E. M. P. et al. (Eds.). VI Botânica no Inverno. São Paulo, SP: Instituto de Biociências da Universidade de São Paulo, Departamento de Botânica, 2016. cap. 10, p. 93-104.

ROSSETTO, C. J. et al. A. Mango resistance to fruit flies I - varietal selection and mechanisms of resistance. Acta Horticulturae, 820: 575-580, 2009.

SÁ, R. F. et al. Índice de infestação e diversidade de moscas-das-frutas em hospedeiros exóticos e nativos no polo de fruticultura de Anagé, BA. Bragantia, 67: 401-411, 2008

SANTOS, O. O.; ANDRADE, L. L.; BITTENCOURT, M. A. L. Moscas-das-frutas (Diptera: Tephritidae) em armadilhas tipo McPhail e frutos hospedeiros no município de Ilhéus, Bahia. Magistra, 20: 398-402, 2008

SANTOS, W. G. N. et al. Moscas-das-frutas em um pomar comercial de mangueira, no litoral do Rio Grande do Norte. Agropecuária Científica no Semiárido, 9: 1-13, 2013.

SILVEIRA NETO, S. et al. Manual de Ecologia de Insetos. 1. ed. São Paulo, SP: Agronômica Ceres, 1976. $420 \mathrm{p}$.

SIMÕES, C. M. O. et al. Farmaconosia: do produto natural ao medicamento. 1. ed. Porto Alegre, RS: Artmed, 2017. $136 \mathrm{p}$.

TRASSATO, L. B. et al. Primeira ocorrência de Ceratitis capitata (Wied.) no estado de Roraima, Brasil. Revista Agro@mbiente, 11: 88-91, 2017. 